\title{
Modelling the Inundation and Morphology of the Seasonally Flooded Mayas Wetlands in the Dinder National Park-Sudan
}

\author{
Khalid Hassaballah $^{1,2,3}$ (D) Yasir Mohamed ${ }^{1,2,3} \cdot$ Amgad Omer $^{4} \cdot$ \\ Stefan Uhlenbrook ${ }^{1,2,5}$
}

Received: 7 January 2019 / Accepted: 15 June 2020 / Published online: 8 July 2020

(C) The Author(s) 2020

\begin{abstract}
Understanding the spatiotemporal dynamics of surface water in varied, remote and inaccessible isolated floodplain lakes is difficult. Seasonal inundation patterns of these isolated lakes can be misestimated in a hydrodynamic model due to the short time of connectivity. The seasonal and annual variability of the Dinder River flow has great impact on what is so called Mayas wetlands, and hence, on the habitats and the ecological status of the Dinder National Park. This variability produces large morphological changes due to sediment transported within the river or from the upper catchment, which affects inflows to Mayas wetlands and floodplain inundation in general. In this paper, we investigated the morphological dimension using a quasi-3D modelling approach to support the management of the valuable Mayas wetlands ecosystems, and in particular, assessment of hydrological and morphological regime of the Dinder River as well as the Musa Maya. Six scenarios were developed and tested. The first three scenarios consider three different hydrologic conditions of average, wet and dry years under the existing system with the constructed connection canal. While the other three scenarios consider the same hydrologic conditions but under the natural system without an artificial connection canal. The modelling helps to understand the effect of human intervention (connection canal) on the Musa Maya. The comparison between the simulated scenarios concludes that the hydrodynamics and sedimentology of the Maya are driven by the two main factors: a) the hydrological variability of Dinder River; and b) deposited sediment plugs in the connection canal.
\end{abstract}

Keywords Hydrodynamic modelling $\cdot$ Hydrological variability $\cdot$ Morphological changes $\cdot$ Dinder River. Mayas wetlands · Delft3D

Khalid Hassaballah

k.hassaballah@yahoo.com

Extended author information available on the last page of the article 


\section{Introduction}

Floodplain inundation and connectivity research in surface hydrology and geomorphology has experienced substantial evolution in the last decade (Heckmann et al. 2018). Previous studies concerned with hydrology (e.g., Bracken and Croke 2007) and geomorphology (Bracken et al. 2015; Brierley et al. 2006; Heckmann et al. 2018), consider hydrological and sediment connectivity as a degree to which rivers facilitates the transfer of water and sediment into its floodplain.

It is well known that wetlands located in floodplains play a crucial role in maintaining the ecological functioning of the river ecosystem. They are characterized by high biodiversity, and hence, have attracted attention for preservation and restoration worldwide (Rebelo et al. 2012). The riverine wetlands reduce flood peaks and provide habitats for endangered species (Popescu et al. 2015). Ramsar Convention on wetlands recognizes wetlands as elements that need to be treated as part of the river system, and not as standalone units.

Floodplain wetlands are the most productive and valuable lands in terms of storage of flood water, groundwater recharge, retention of nutrients and unique habitat for wildlife ( $\mathrm{Li}$ et al. 2019). Fernandes et al. (2018) emphasized that in compound channels, the velocity gradient between the main channel and the floodplain flows leads to a flow structure more complex than in common single channels.

The role of flow and channel morphology in determining the structure of river ecosystems received little attention until the early 1980s (e.g., Nowell and Jumars 1984). River rehabilitation and restoration requires good understanding and precise modelling. This includes the relationships between hydrological patterns, morphological processes and ecological responses in the river and its floodplain (Arthington et al. 2010).

Floodplain wetlands are existing all around the world. Inundation of floodplains by a combination of surface water and groundwater is not common (Bradley 1997). Previous studies on hydrological connectivity between river and its floodplain have considered such habitats as oxbow lakes (e.g., Glińska-Lewczuk 2009; Gumiri and Iwakuma 2002; Zeug and Winemiller 2008), floodplain lakes/wetlands (e.g., Fernandes et al. 2018; Lew et al. 2016; Santisteban et al. 2019; Tan et al. 2019), seasonal wetlands (e.g., Li et al. 2019; Yu et al. 2015) and depression wetlands (e.g., Cook and Hauer 2007; De Steven and Toner 2004).

These previous studies of hydrological connectivity focused mainly on wetlands and small lakes that are either permanently connected to rivers or lakes or are isolated from major water bodies, and therefore, have only subtle water-level fluctuations.

Assessment of the temporal and spatial morphological changes of floodplain and Mayas wetlands of the Dinder River in Sudan is very complex. Therefore, it is important to understand the hydrological processes of such ecosystem. A few studies have been conducted on watershed management and climate variability of the Dinder basin (e.g., AbdelHameed et al. 1997; Basheer et al. 2016). However, the available literature does not show studies on inundation and flooding mechanism of Mayas wetlands.

The Mayas wetlands of the Dinder River represent homes of very rich flora and fauna system of the Dinder National Park (DNP). DNP is in the eastern part of Sudan, close to its border with Ethiopia. The Dinder River is a seasonal river. It provides about $6 \%$ of Blue Nile annual flow. Wetland inundation dynamics exert a strong control on processes for wildlife animals during the dry season, such as plant productivity and water availability (AbdelHameed et al. 1997). The inundation pattern of Mayas wetlands affects the vegetation pattern and type, and it governs the life cycle of the biota. Flood inundation allows for circulation of organisms 
and mineral substances. It also enriches waters with dissolved oxygen, which in turn will enrich the nutrients that feed aquatic plants.

Dinder River rises in the Ethiopian highlands. The land use and land cover changes (LULCCs) in the Ethiopian highlands (as reported by Bewket and Sterk 2005; Hassaballah et al. 2017; Hurni et al. 2005; Teferi et al. 2013; Teferi et al. 2010; Zeleke and Hurni 2001) have apparently contributed to the existing high rate of soil erosion and land degradation in these areas (Bewket and Teferi 2009). According to an estimate by FAO (1986), some $50 \%$ of the highlands of Ethiopia are already significantly eroded. Therefore, understanding the consequences of soil erosion in the Ethiopian highlands, and integrating that into the sediment transport processes are very important for better management of the DNP ecosystems. The Mayas wetlands feeders play a significant role in ecosystem conservation in view of the fact that it serves to route water and sediment across and out of the Mayas wetlands.

The hydrological processes of the Dinder and Rahad basins are not well understood; in particular, the predictions of hydrological and morphological dynamics have not been studied before. Therefore, in-depth hydrological and morphological studies of the basins and their interactions with the ecosystem are very essential to inform better management of water resources and ecosystem of the Dinder and Rahad basins. The ecologically wealthy DNP depends mainly on the ecosystem services provided by the Mayas wetlands particularly during the dry season. During the past two decades, the areas of some Mayas wetlands inside DNP have radically decreased. Such Mayas wetlands can no longer store enough water to satisfy the needs of the wildlife populations throughout the dry season. Some Mayas wetlands were completely dry up, and the causes are not understood. The drying of Mayas wetlands could have serious impacts on wildlife populations that depend on them for water and food in the dry seasons. Thus, the entire ecosystem of the DNP seems vulnerable to hydrological and morphological changes because it largely depends on the Mayas wetlands.

The management plan of the DNP identifies a number of measures for conservation of the park, which focus on human activities such as control of poaching inside the park, control of mechanized agriculture around the park and adaptation of biosphere reserve concept. Ad hoc clearance of sediment from the feeders of Mayas is also practised to rescue wildlife in some years, which may not be sustainable. Only a few measures have been implemented due to lack of funds (Mutasim and Frazer 2004). Construction of connection canals to enhance the filling of the Maya complicates its hydrology (Hassaballah et al. 2016). The practice of constructing diversion canals is a common practice in many wetlands to facilitate drainage and improve the functioning of wetlands (Tooth et al. 2014).

In addition to the human influences, the major driving force for changes in the Mayas system is the hydrological regime of the water supply system of Mayas wetlands, particularly seasonal floods. Gomoiu (1998) reported that the hydrological regime of a river system allows for the exchange between aquatic and terrestrial habitats, ensuring that all components of the system are functioning. In the long-term, decision-makers in the area need to know which measures to implement for ecosystem rehabilitation or conservation, and how these will impact or improve the water system. There is no information on the hydrology or morphology of the Dinder River except of discharge measurement at the station located just before the confluence with the Blue Nile. New field measurements within the DNP has been conducted as part of this study from 2013 to 2016 .

This article presents an attempt to apply hydrodynamic and morphological modelling to support decision making for the conservation of Mayas wetlands within the DNP. A quasi-3D numerical model using Delft3D software was built to simulate the behaviour of the Mayas 
system as a response to hydrological variability. Musa Maya was chosen as a pilot Maya for applying the hydrodynamic and morphology modelling approach.

\section{Regional Setting}

The Dinder and Rahad are the most downstream tributaries of the Blue Nile and meet the Blue Nile inside Sudan. There are additional eight major tributaries of the Blue Nile located further upstream in Ethiopia. The Dinder River joins the Blue Nile at the village Al-Rabwa, approximately $115 \mathrm{~km}$ downstream of Al-Gewisi town (Fig. 1).

The total catchment area is about $34,964 \mathrm{~km}^{2}$ and its catchment in Ethiopia is about $16,000 \mathrm{~km}^{2}$. The monthly precipitation records indicate a summer rainy season, with highest totals in the months of June-September (Block and Rajagopalan 2006).

The flow records of the Dinder between (1972-2015) show an annual average flow of about $2.20 \times 10^{9} \mathrm{~m}^{3} /$ year. Figure 2 shows the high variations in the annual flow of Dinder during the period (1972-2015). Considering the seasonal flow behaviour of the Dinder, the river brings a considerable discharge in only four months of the year (July-October). The flow duration extends from July to December. For about half a year, from January to June the river bed is left with only a few pools which may hold water until the next rainy season.

\subsection{Dinder National Park (DNP)}

The DNP $\left(10,291 \mathrm{~km}^{2}\right)$ is a vital ecological area in the arid and semi-arid Sudan-Saharan region. It was proclaimed as a national park in 1935 following the London Convention for the Conservation of African Flora and Fauna (Dasmann 1972). The park is located in the Southeast of Sudan near the Ethiopian border between longitude $34^{\circ} 30^{\prime} \mathrm{E}$ and $36^{\circ} 00^{\prime} \mathrm{E}$ and latitude $11^{\circ} 00^{\prime} \mathrm{N}$ and $13^{\circ} 00^{\prime} \mathrm{N}$ (Fig. 1). The water system of the park includes the Dinder and the Rahad rivers, their tributaries and the Mayas. Mayas are wet meadows (wetlands) and oxbow

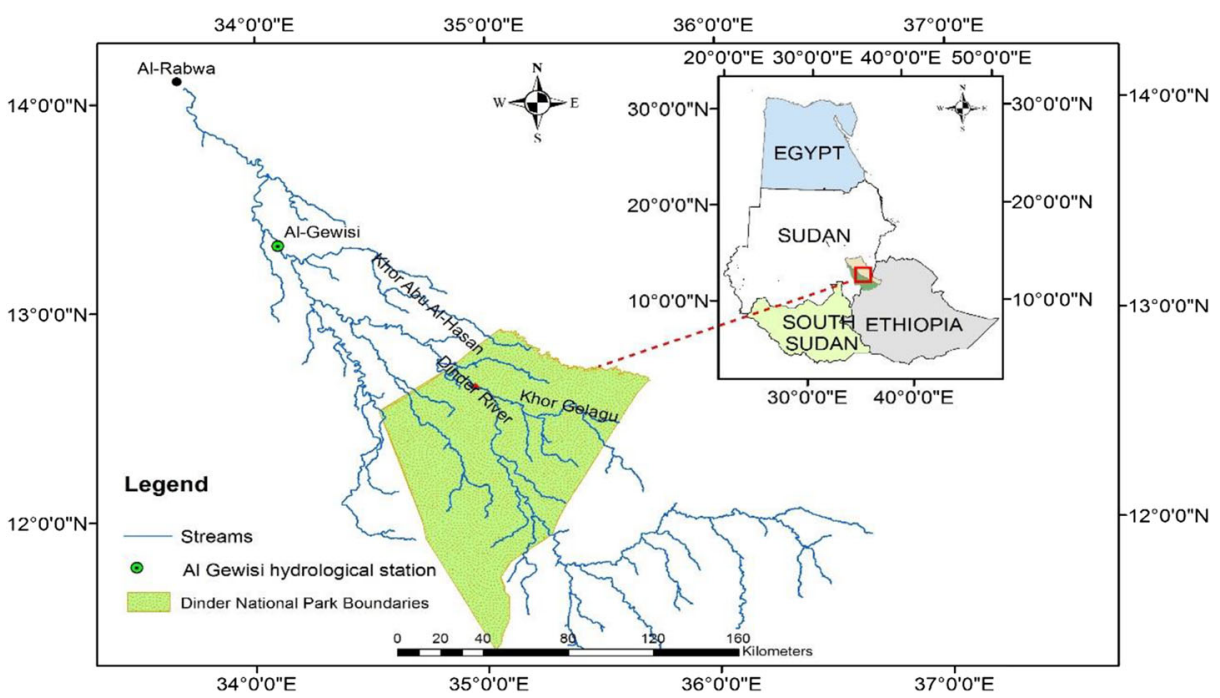

Fig. 1 The study area of the Dinder River basin and the Dinder National Park (DNP) 


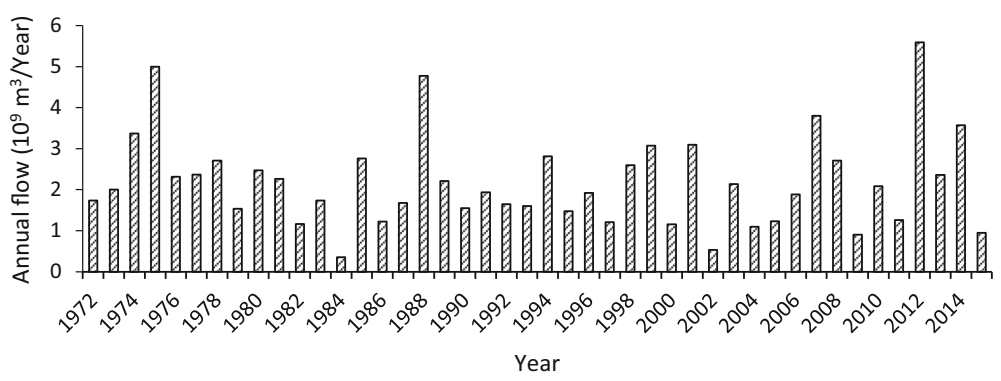

Fig. 2 The annual flow of the Dinder River at Al Gewisi station

lakes naturally formed along the floodplain of the river and connected to the main river via feeders. During the wet season, Mayas are flooded if the water level in the river is high enough to flow into the Mayas.

The ecological water requirements from the Dinder River support the rich ecosystem of the DNP, both the aquatic species and animals in the park. The river is also the main source of water for the diverse ecosystems of the Mayas in the DNP. The river flood plays a key role in hydrological and ecological integrity as a connectivity corridor between the river channel and the Mayas floral and faunal habitat. The absence of flood leads to dryness and degradation of the Mayas and loss of biodiversity.

It was noticed that some of the Mayas wetlands do not receive water in recent years. The hydrology of the Mayas is very complex and not fully understood. The sediment load that builts upon the feeder channels and on the bed of the Mayas is claimed to have an influence on the Mayas hydrology. Or there may be just natural changes which keep the balance of the natural river system, nobody knows.

\subsubsection{Description of the Pilot Musa Maya}

Musa Maya is situated about $10 \mathrm{~km}$ northwest of the Gelagu camp (Fig. 3). In 1970s, it was one of the most productive Mayas and an important source of water and pasture during the dry season. During the last three decades, the Maya has experienced consecutive years of drought and observed to be dominated by grass tolerant to drought. There is no distinct channel which connects the Maya to the Dinder River. However, in 2012, a connection canal was constructed to supply water to the Maya after consecutive years of drought.

\section{Data and Methods}

\subsection{Collected Data}

A quasi-3D numerical model has been built to cover the river and the wetlands area, using Delft3D software. This model requires a topography grid map, surface roughness grid map, observed discharge data and cross sections of Dinder River. STRM (Shuttle Radar Topography Mission) DEM of $90 \mathrm{~m}$ resolution, produced by the National Aeronautics and Space Administration (NASA), was used. The data was expressed in geographic coordinates (latitude/longitude) and was horizontally and vertically referenced to the WGS84. The model extent covers an area of about $105 \mathrm{~km}^{2}$ inside the DNP (Fig. 3). Since the vertical accuracy of 


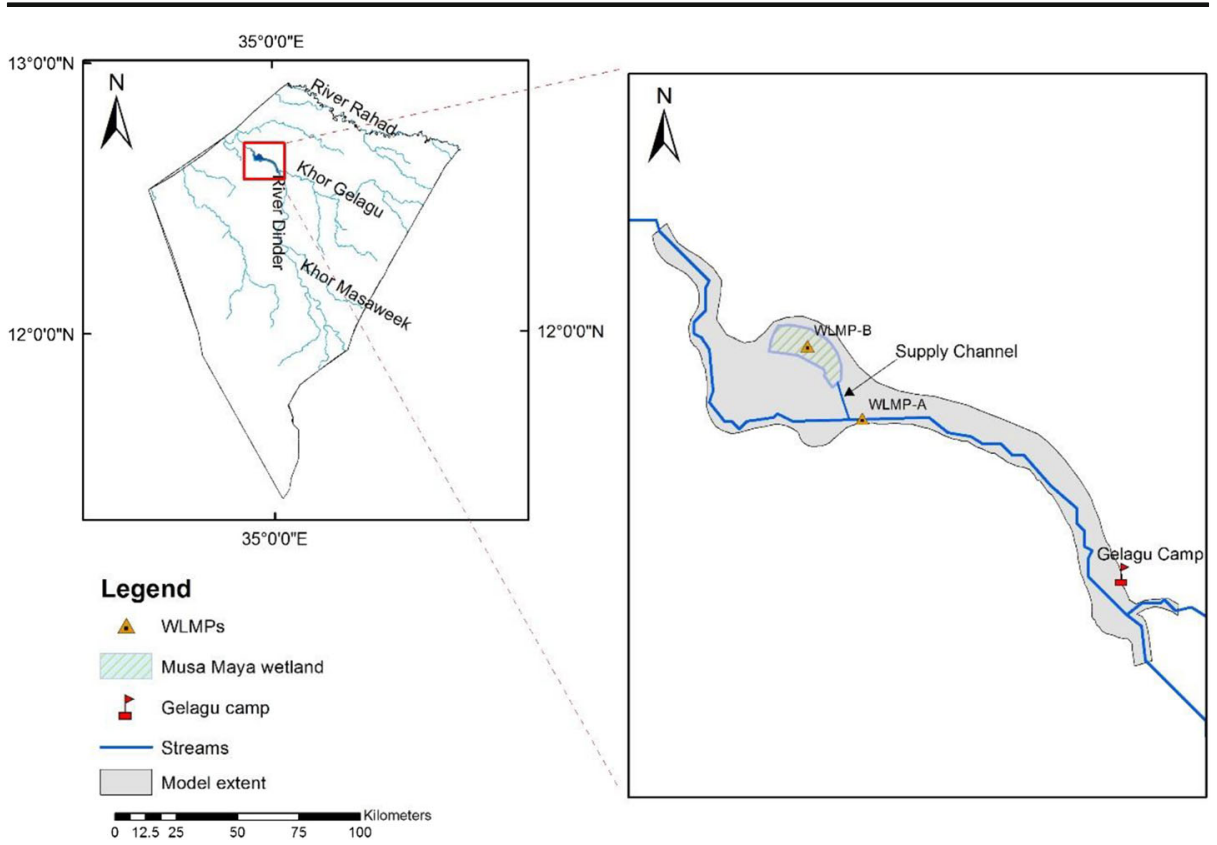

Fig. 3 DNP study area (left) and the model extent (right)

the $90 \mathrm{~m}$ resolution DEM performs poorly in areas of moderate topographic variation and forestry area, a field topographic survey was conducted using an ordinary level and GPS to generate a DEM with higher accuracy for the model domain within the DNP.

\subsubsection{Water Level Data}

Due to the absence of water level measurements within the pilot area inside the DNP, a Divers network was established in June 2013 to collect data for this study. The network consists of two Mini-Divers that measure water level, temperature and atmospheric pressure and one Baro-Diver for atmospheric correction. The divers were set to take measurements automatically on an hourly basis. The divers were reasonably installed as follows: the first Mini-Diver was installed just upstream of the confluence of the Dinder River with the feeder of Musa Maya to measure the Dinder River water level, and the second Mini-Diver was installed in the middle of the pilot Musa Maya to measure the Maya's water level. The Baro-Diver was installed near the other two Mini-Divers. This diver measures atmospheric pressure and is used to compensate for the variations in atmospheric pressure measured by the other two MiniDivers. The locations of the water level monitoring points (WLMP) are shown in Fig. 3.

\subsubsection{River Cross Sections}

During June 2013 (dry period), a topographic survey was conducted to measure river cross sections. The survey covered 23 cross sections; 18 of them in the Dinder River covering a reach of $20.0 \mathrm{~km}$ inside the DNP; 3 cross sections in Khor Gelagu; and 2 in the connection canal of Musa Maya. Each cross section was surveyed from the highest flood level on the left bank of the river and crossing the river to a reasonable mark above the highest flood level on 
the right bank of the river. Ordinary land levelling was used for measuring the elevations and a GPS for position fixing. The same cross sections were repeated in 2016 to examine morphological changes.

\subsubsection{Sediment Data}

Sediment data for the Dinder (suspended sediment concentration, no grain size analysis) are available for the years (1992-1995). The study site (within the morphological model domain) is completely inaccessible during the rainy season. Thus, no suspended sediment data were collected from the study site. The average suspended sediment concentrations were derived from the available daily data at Al-Gewisi station (1992-1995) and used for this study. Soil samples were taken from the pilot Maya and the Dinder River banks and bed during the field campaign in June 2016. Only suspended sediment can enter the Maya. Therefore, the grain size distribution of the deposited sediment on the bed of the Maya is assumed to be equal to the grain size distribution of the suspended sediment of the Dinder River.

\subsection{River Channel Data Analysis}

River channel sinuosity in the study reach is low $(\mathrm{P} \approx 1.28)$. Analysis of the surveyed cross sections indicates that the river width within the study area varies between $180 \mathrm{~m}$ and $800 \mathrm{~m}$ with an average bank-full depth of $4 \mathrm{~m}$ during the survey period. Comparison of the cross sections measured in 2013 and 2016 at the same locations (Fig. 4) shows that the changes vary from erosion to a deposition with maximum bank erosion reaching $63 \mathrm{~m}$ on the right bank at cross section 12 less than $1.0 \mathrm{~km}$ downstream of the constructed connection canal.

Figure 5 shows that the water level in the Musa Maya has similar pattern to that of the Dinder River during the flood season. This indicates that the Maya received its water from the river through the connection canal, while the contribution of direct rainfall and sheet flow from the surrounding area is very small.

The analysis of the daily average sediment data for the period 1992 to 1995 showed that the suspended silt concentrations ranged between a maximum of $3339 \mathrm{mg} / \mathrm{L}$ at the beginning of the flood season (July) and a minimum of $140 \mathrm{mg} / \mathrm{L}$ in October (Fig. 6).

The analysis of the bed sample taken from the middle of the Maya (during the survey of 2013) shows fine particles with a $D_{50}$ of $22 \mu \mathrm{m}$. Silt is the dominant type of sediment in suspension, and it represents about $59 \%$ of the samples. Sand represents $32 \%$ and clay represent the remaining $9 \%$ of the suspended sediment materials (Fig. 7).

The analysis of the bed materials (Fig. 8) at the upstream boundary shows a $\mathrm{D}_{50}$ of $420 \mu \mathrm{m}$, decreased to $290 \mu \mathrm{m}$ at the downstream boundary of the model domain. Averaging results in $\mathrm{D}_{50}$ of $355 \mu \mathrm{m}$ for the model river reach. Thus, a $\mathrm{D}_{50}$ of $355 \mu \mathrm{m}$ was adopted for the Dinder River within the model domain. The bed sample taken from a location just downstream of the confluence of Khor Gelagu (tributary of the Dinder) shows coarse materials with a $\mathrm{D}_{50}$ of $2600 \mu \mathrm{m}$. This can be attributed to the upstream contribution of coarser bed materials from Khor Gelagu tributary. We have also taken three samples from the river bank at the upstream boundary, downstream of the junction with Khor Gelagu and at the downstream boundary of the model domain. Analysis of the grain size distribution (Fig. 8) of these samples shows $\mathrm{D}_{50}$ of 57, 29 and $43 \mu \mathrm{m}$ for the upstream boundary, the middle part of the river reach and the downstream boundary, respectively resulting in an average $\mathrm{D}_{50}$ of $43 \mu \mathrm{m}$. 

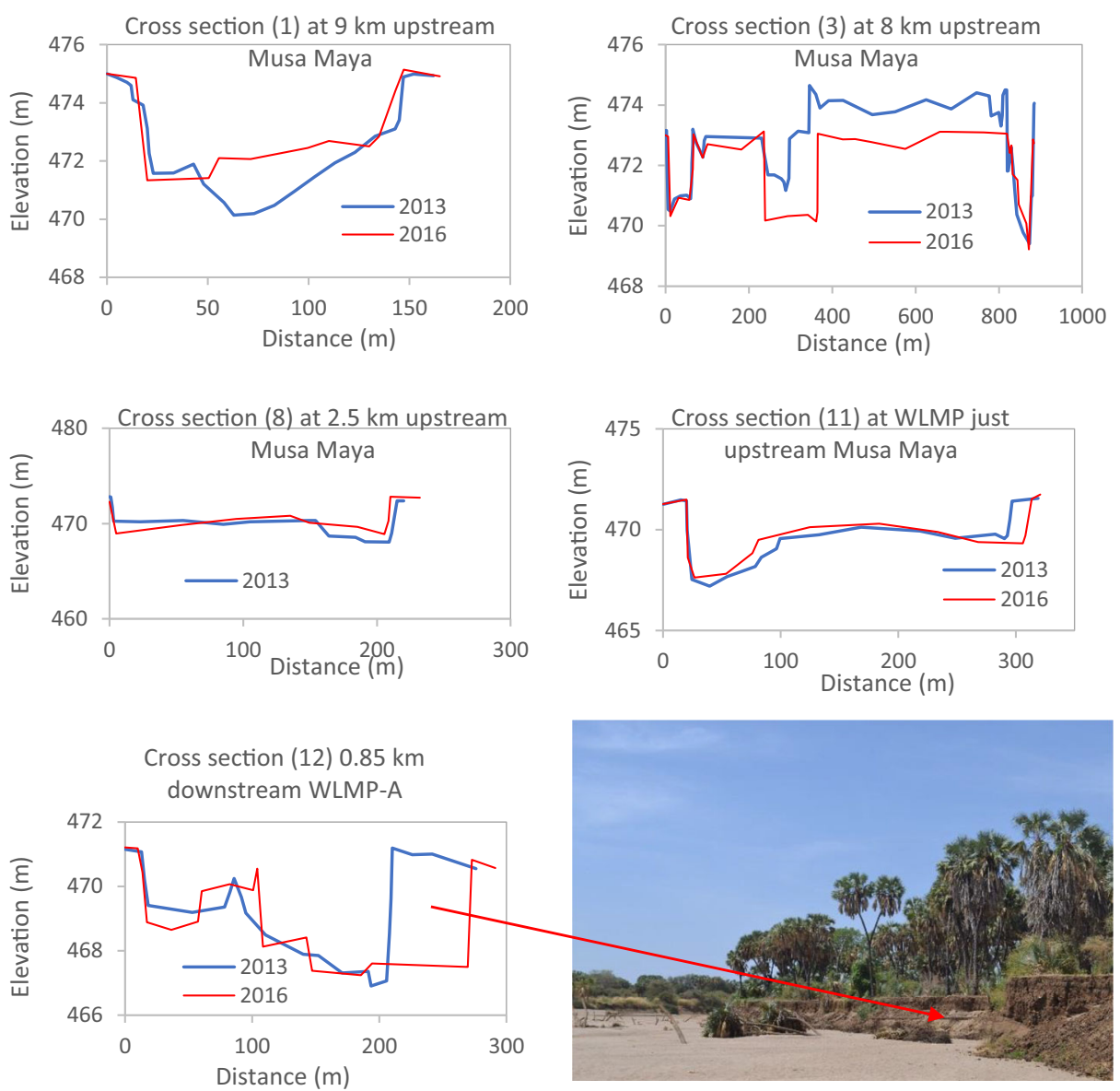

Fig. 4 Comparison of the surveyed cross sections between 2013 and 2016

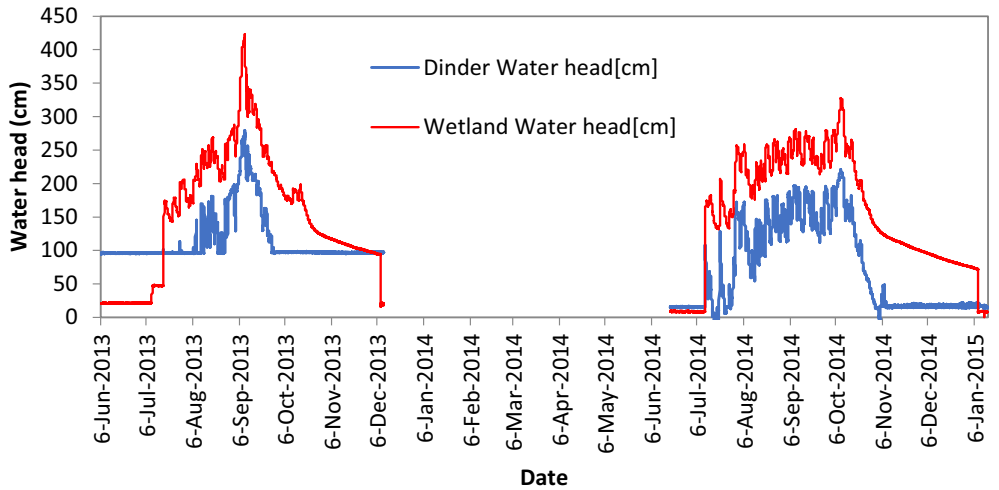

Fig. 5 Readings of the automatic gauges (water column above Diver (cm)) in Dinder River and in the pilot Musa Maya 


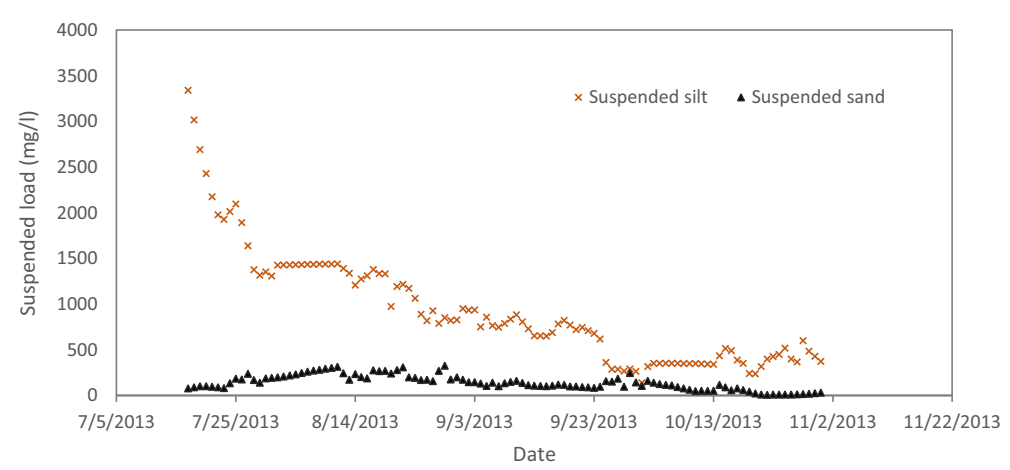

Fig. 6 The daily average suspended sediment concentration at Al-Gewisi station in Dinder River

\subsection{Method}

Since the objective of this study is to assess the hydrological and morphological regime of the Dinder and Musa Maya, the hydrodynamic and morphological simulation is a plausible approach despite data limitation to at least understand the mechanism of water flow and sedimentation of the connection canal and Musa Maya.

In this study, we developed a quasi-3D morphological model of the Musa Maya wetland in order to understand the flooding mechanism and the morphological changes in the area. Bathymetry of the model is shown in Fig. 9. The measured flow data at Al-Gewisi station were provided by the Ministry of Irrigation and Water Resources of Sudan. The model has been set to a combination of grids, distributed over the area of the wetland. The grid cell size varies based on the topography and model domain with a total number of computational cells of 47,124.

Delft3D software was used to simulate both the hydrodynamics and the morphology of the Dinder River system and the sediment processes in Musa Maya. Delft3D software is developed by Deltares (http://oss.deltares.nl/web/delft3d) to simulate hydraulic phenomena in river, estuarine and coastal areas. A detailed description of the open-source code of the model is reported by Lesser et al. (2004). The overland flow and channel flow module in Delft3D that was set for the study area included a topography grid map, surface roughness grid map, observed discharge data and the surveyed cross sections of the Dinder River.

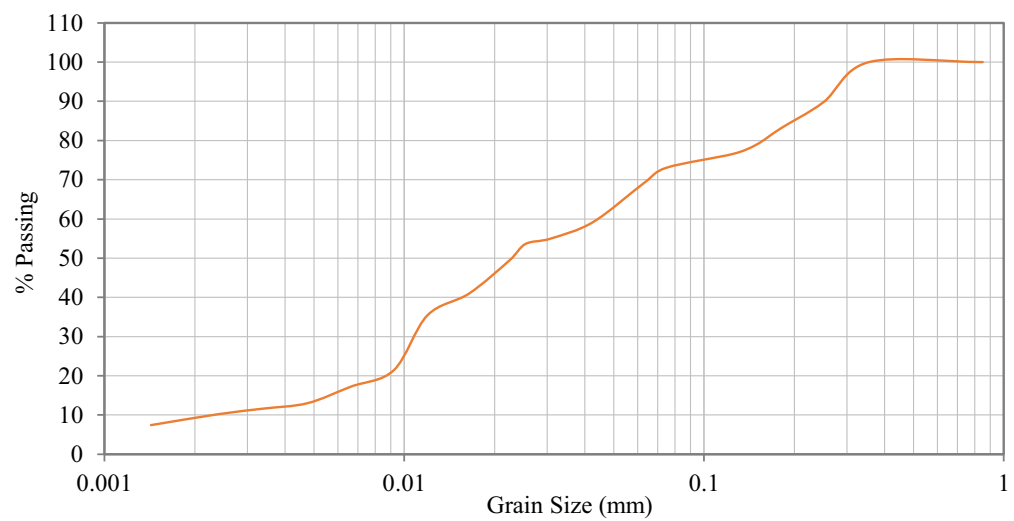

Fig. 7 Grain size distribution for Musa Maya (bed sample) 


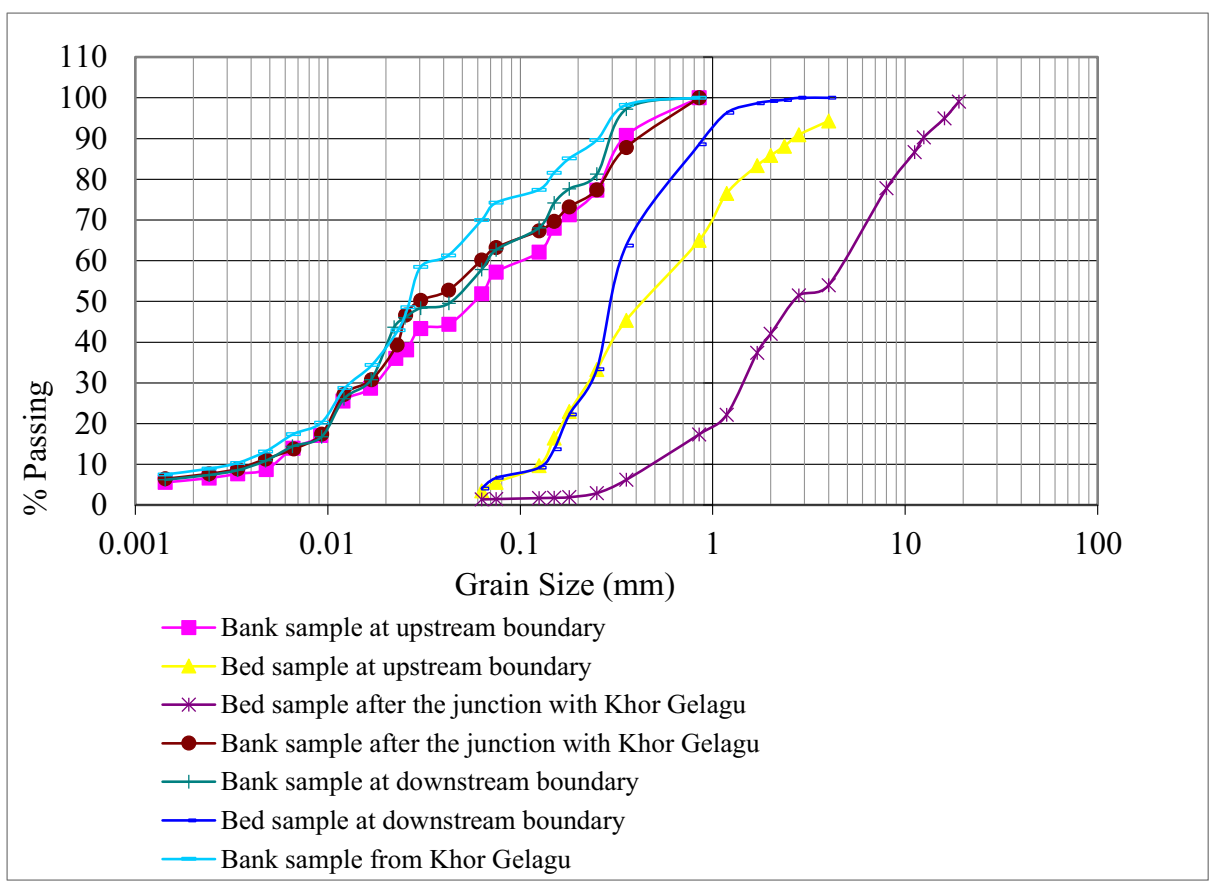

Fig. 8 Grain size distribution of the collected soil samples within the modelling area

\subsection{Setup of the Hydrodynamic Model}

We applied Delft3D to a $20 \mathrm{~km}$ reach of the Dinder River between Gelagu camp and up to few kilometres downstream of the pilot Musa Maya (see Fig. 3). Topography data were available

Bathymetry [m]

$=<-479.0$

= $<-478.0$

$=<-477.1$

$=<-476.1$

$=<-475.2$

$=<-474.3$

$=<-473.3$

$=<-472.4$

$=<-471.4$

$=<-470.5$

$=<-469.5$

$=<-468.5$

$<-467.6$

$=<-466.6$

$=<-465.7$

$=<-464.8$

$=<-463.8$

$=<-462.9$

$=<-461.9$

$=<-461.0$

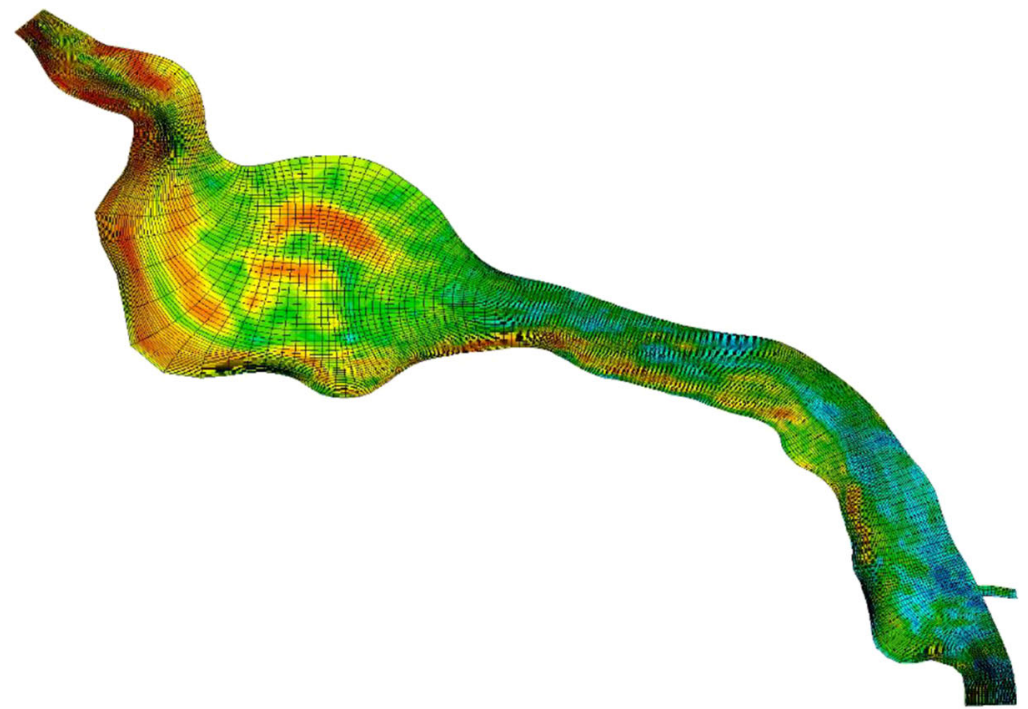

Fig. 9 Bathymetry of the study area, computational grid and bed elevations in 2013, in m.a.s.1 
from 90 m resolution DEM data from the Shuttle Radar Topography Mission (SRTM). Mukul et al. (2015) reported that SRTM data over Africa have a mean absolute height accuracy of $16 \mathrm{~m}$ (with $90 \%$ confidence)/RMSE $\sim 10 \mathrm{~m}$. SRTM requires processing to remove vegetation effects in order to obtain 'bare earth' DEM as the X and C band radars used do not fully penetrate vegetation canopies (Wilson et al. 2007). To achieve this, we used the ground survey data to correct the DEM and to create a first-order 'bare earth' DEM for this reach. Channel topography was approximated using the measured cross sections of the Dinder River reach upstream and downstream of the pilot Maya. These data were also used to obtain bank-full depth in the river channel, which may drive performance in river/Mayas water exchange. We assumed that direct runoff and rainfall inputs to the Mayas balanced losses due to evapotranspiration and infiltration. Thus, detailed floodplain hydrologic processes were not considered.

\subsection{Boundary Conditions}

Three boundaries were set, two upstream boundaries of discharge inflow into the model, and the downstream boundary contained a discharge-stage relation. The water entered the Dinder system through the upstream boundaries that were set as a river channel in the model. The model was run for the wet season of year 2013 with a computational time step of $12 \mathrm{~s}$ starting from the dry condition. A constant Manning roughness coefficient $n$ was used. The $n$ value was changed during the calibration process to obtain the best hydrodynamic calibration. Al-Gewisi station, approximately $130 \mathrm{~km}$ downstream of the DNP, is the only hydrological station on the Dinder River. Therefore, the computed flow at a location just upstream of Gelagu camp through rainfall-runoff modelling (Hassaballah et al. 2017) was used as an upstream boundary condition for the model domain. The downstream boundary condition was set as a Q-H relation which was calculated based on the cross section geometry of the Dinder River at a location approximately $10 \mathrm{~km}$ downstream the gauge measuring station. The measured water levels (20132014) at two locations just upstream of the pilot Maya and inside the Maya were used for model calibration. The selection of the simulation time step depends on several parameters, such as the grid size of the model, the water depth, the required accuracy and the stability of the model during simulation. The Courant number $(\mathrm{Cr})$ is defined as:

$$
C_{r}=\frac{\Delta t \sqrt{g h}}{[\Delta x, \Delta y .]}
$$

For model stability, the $C_{r}$ should not exceed a value of 10. (Deltares 2010). In the hydrodynamic model and the selected schematisation of the grid cells, the time step used is $0.2 \mathrm{~min}$ and the value of $\mathrm{Cr}$ varies in space and time. The values of other numerical parameters adopted in the model coincide with the default values of the Delft3D software. During the model setup phase, inaccuracies due to the large size of the computational grid cells were compensated for by manual adjustments of topographic levels, ensuring that the "thalweg" elevation in the model is close to the measured one.

\subsection{Calibration of the Hydrodynamic Model}

Estimation of model parameter values is difficult even with highly specialized laboratory experiments. A practical approach is to estimate such parameters from available process data 
or from the literature. Typically, only a subset of the parameters can be estimated due to restrictions imposed by the model structure, lack of measurements, and limited data.

In this study, the various model parameters were adopted from previous literature from the region (e.g., Omer et al. 2015). Then, manual calibration through adjusting the model topography and the Manning roughness parameter in an iterative way until the observed water level exhibited an acceptable level of agreement with model output.

Many simulations have been conducted using variable bed roughness until the modelled water level closely fitted the observed water level. This was obtained with a Manning roughness value of 0.035 . Then, a systematic adjustment of the topography was made to improve the calibration fitting. The model results were compared with the water levels measured at the pilot Musa Maya and the Dinder River just upstream the pilot Maya.

The calibration results of the water levels are shown in Fig. 10. The RMSE and the NSE (Nash and Sutcliffe (1970) were used to evaluate the model performance. Figure 10a,b show best values obtained for NSE 0.61 and 0.73 associated with RMSE values of $0.39 \mathrm{~m}$ and $0.27 \mathrm{~m}$ for the Dinder River and Musa Maya, respectively. Figure 10c,d show the calibration results after a systematic adjustment of the topography is made. The best values obtained for NSE are 0.89 and 0.67 associated with RMSE values of $0.14 \mathrm{~m}$ and $0.30 \mathrm{~m}$ for the Dinder River and Musa Maya, respectively. The modelled water levels matched closely for the Dinder gauge and were under-predicted by a maximum value of $0.26 \mathrm{~m}$ at high water level. While, at Musa Maya, the model is over-predicting the stage at low water levels and under-predicting the stage at high water level by a maximum value of $0.81 \mathrm{~m}$. This is likely due to an error in the floodplain topography resulted from the combination of the DEM and the surveyed topography.

(a)

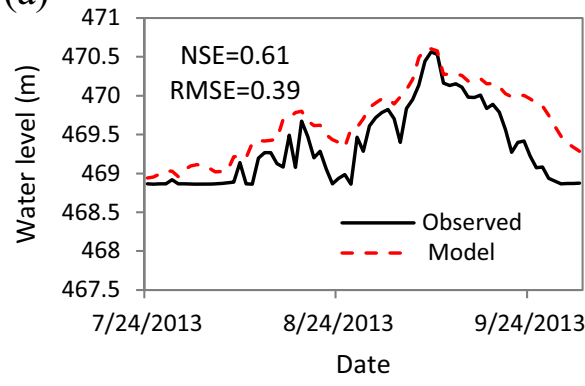

(c)

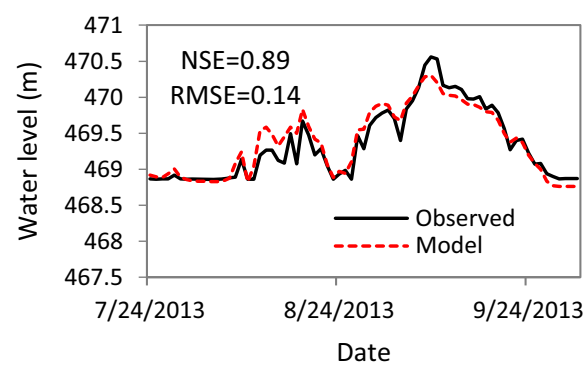

(b)

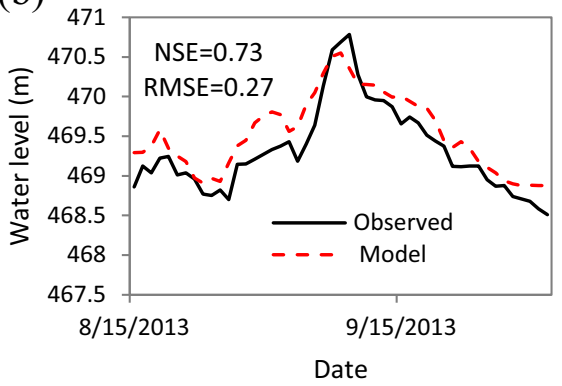

(d)

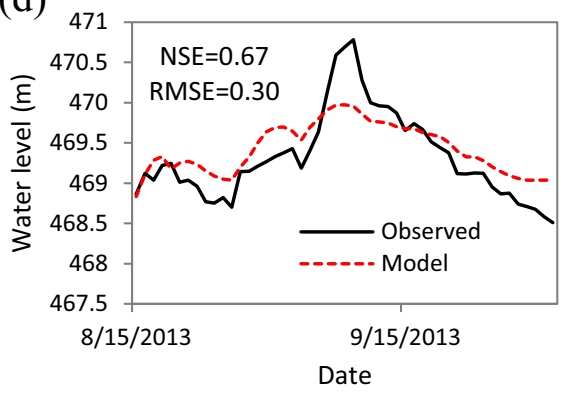

Fig. 10 Results of hydraulic model calibration, (a, b) Dinder River and Musa Maya before topography adjustment, (c, d) Dinder River and Musa Maya after topography adjustment 
Despite the availability of digital elevation models plus extensive field surveys carried out in 2013 through 2016 in a very harsh forested environment, the topography of the Mayas wetlands floodplain might not be very accurate to model flood propagation. However, it is satisfactory to demonstrate how filling and emptying of Mayas wetlands occurs. For seasonal isolated Mayas, it is difficult to determine boundary conditions due to the complex flow patterns and limited in situ observations. Uncertainties in the hydrodynamic model might result in smaller defined Mayas wetlands boundaries, bathymetric variations and unconsidered groundwater recharge/discharge.

In general, the calibration results indicate that the Delft3D performance is reasonably good to understand the inundation mechanism of the Maya. Then, the model was used to simulate the filling mechanism using variable river flows with wet, average and dry hydrological years and keeping other model parameters without change. Model validation with different data set is the second step after the calibration if another subset of data is available to perform this step. A substantial effort has been made to collect and gather data from a very harsh and inaccessible environment. These data for only two years were used for model calibration. Due to time and cost limitations, we were not able to repeat some of the measurements (e.g., water level and cross sections) needed for model validation.

\subsection{Setup of the Morphological Model}

The calibrated hydrodynamic model is updated to include the morphological setup. The morphological model is based on the hydrodynamic model, with the aim to simulate sediment process inside the pilot Maya and morphological changes in the river reach during the two flood seasons of 2013 and 2016. For non-cohesive sediment (sand), the Van Rijn (1984) transport formula is used to calculate the erosion and deposition. Whilst, for cohesive sediment fractions (silt) the fluxes between the water phase and the bed are calculated with the wellknown Partheniades-Krone formulations (Partheniades 1965). The model was calibrated on the measured cross sections changes during these two periods derived from the field survey data. There were no data available on soil stratification. The morphological computations were excessively time-consuming due to a large number of computational cells. These large numbers of cells were unavoidable due to the complexity of the processes to be simulated, such as 2D hydrodynamics, bed change and suspended load transport, and sediment deposition.

The daily average sediment concentration of the river available for the period (19921995 ) is used as an upstream morphological boundary condition. Due to lack of measurements and limited morphological data in the study area, estimation of model parameters is difficult even with highly specialized laboratory experiments. A practical approach is to estimate such parameters from available process data or from the literature. Therefore, the various morphological model parameters were adopted from previous literature from the region (i.e., Omer et al. 2015). The adopted parameters are presented in Table 1.

The critical bed shear stress for deposition of suspended solids is kept at $1000 \mathrm{~N} \mathrm{~m}-2$ which means that below this value, any particle was free to deposit according to its fall velocity and depending on the computed bed shear stress. On the other hand, the critical shear stress for erosion is increased to $1 \mathrm{~N} \mathrm{~m}-2$ which means unless the bed shear stress exceeds this value, no bed erosion takes place; in addition, the erosion parameter rate is reduced to $2 \mathrm{mg} \mathrm{m}-2 \mathrm{~s}-1$. These values are defined from the calibration process trials. 
Table 1 Values of physical parameters adopted from (Omer et al. 2015)

Physical parameter

Calibrated value

Spiral flow $-(\beta)$

Horizontal eddy viscosity

Horizontal eddy diffusivity

Specific density of sediment

$\mathrm{C}_{\text {soil }}$ (reference density of hindering settling)

$\mathrm{D}_{50}$

Dry density of sand

Dry density of silt (deposited suspended solids)

Ws,0 (settling velocity of suspended solids)

$\tau_{c}$ (critical shear stress for erosion of silt)

$\tau_{d}$ (critical shear stress for deposition of suspended solids)

$M$ (erosion rate of deposited silt)

Manning roughness ( $n$ )

$0.5(-)$

$1.0\left(\mathrm{~m}^{2} \mathrm{~s}^{-1}\right)$

$1.0\left(\mathrm{~m}^{2} \mathrm{~s}^{-1}\right)$

$2650\left(\mathrm{~kg} \mathrm{~m}^{-3}\right)$

$1600\left(\mathrm{~kg} \mathrm{~m}^{-3}\right)$

$355 \mu \mathrm{m}$

$2000\left(\mathrm{~kg} \mathrm{~m}^{-3}\right)$

$1200\left(\mathrm{~kg} \mathrm{~m}^{-3}\right)$

$0.005\left(\mathrm{~mm} \mathrm{~s}^{-1}\right)$

$1\left(\mathrm{~N} \mathrm{~m}^{-2}\right)$

$1000\left(\mathrm{~N} \mathrm{~m}^{-2}\right)$

$2\left(\mathrm{mg} \mathrm{m}^{-2} \mathrm{~s}^{-1}\right)$

0.035

\section{Results and Discussion}

\subsection{Floodplain (Mayas Wetlands): Hydrological and Morphological Connectivity}

To understand the hydrological and morphological connectivity of the Maya with the river in terms of filling/emptying, six scenarios were investigated. The first three scenarios consider three different hydrologic conditions of average, wet and dry years under the existing system with the constructed connection canal. The other three scenarios consider the same hydrologic conditions, but under the natural system without the connection canal. This should help to understand the effect of human intervention (e.g., connection canal) on the Musa Maya. In other words, it clearly explains the validity of the quasi-3D modelling approach to support decision making in Mayas wetland management. The average, wet and dry years were defined based on the long-term annual average flow for the years 1900-2016. The long-term annual average flow (1900-2016) is about $2.70 \times 10^{9} \mathrm{~m}^{3}$. This represents over $5 \%$ of the Blue Nile basin's annual flow. All years $\pm 15 \%$ of the average are considered as average years. Years with an annual flow that is $16 \%$ above the average are considered as above average years, and years with an annual flow that is $50 \%$ above the average are considered as wet years. While years with an annual flow that is $16 \%$ below the average are considered as below average, and years with an annual flow that is $50 \%$ below the average are considered as dry years.

\subsubsection{Scenario 1: Average Hydrologic Year under the Existing System with the Constructed Connection Canal}

In this scenario, the system was simulated using the flow of the year 2013 as representative for average hydrologic years $\left(2.36 \times 10^{9} \mathrm{~m}^{3} /\right.$ year) in the existing system (with constructed connection canal). The model results show that the constructed connection canal conveys and maintains the water flow from the river to the Maya "filling phase". This phase begins usually at the end of July when the water level in the main river at the cross section just upstream of the connection canal rises to a level of $469 \mathrm{~m}$ (bed level of the connection canal). This phase continues until the water level reached its maximum levels during the first two weeks of September (Fig. 11a-b). With such average flow, the Maya is partially inundated with variable water depths according to the Maya's topography with a maximum depth of $3.5 \mathrm{~m}$. Other parts 
of the floodplain remain dry with no connection with the river water. This phase is considered as the wet condition of the Maya. As the river water level falls, the "drainage phase" begins through the same connection canal and it continues until the water level is low enough that stagnant (lentic) and dynamic (lotic) waters are completely isolated "isolation phase" (Fig. 11c-d). In this stage, the Maya and the river waters are completely disconnected. The Maya is left with an average water depth of $1.75 \mathrm{~m}$ and estimated water volume of $2.10 \times 10^{6}$ $\mathrm{m}^{3}$. In late November and early December, the river falls to its minimum water level until it runs down to its dry condition.

Due to the construction of the connection canal, a low rate of sediment is transported into the Musa Maya with flood and decreases gradually (Fig. 12a-b). The sediment transport process continues at a low rate until the Maya and the river waters are completely disconnected. The remaining stagnant water in the Maya remains with low suspended sediment concentration (Fig. 12c). Within the river cross section just downstream of the connection canal, high bank erosion on the right and deposition at the middle of the cross section are observed (Fig. 12d). No morphological changes are observed in the connection canal.

\subsubsection{Scenario 2: Wet Hydrologic Year under the Existing System with the Constructed Connection Canal}

In this scenario, the system was simulated using the flow of the year 2012 as a representative for the wet hydrologic years $\left(5.59 \times 10^{9} \mathrm{~m}^{3} /\right.$ year $)$ in the existing system. Similar to scenario 1 , the results show that the constructed connection canal conveys the water flow and maintains the input

(a)

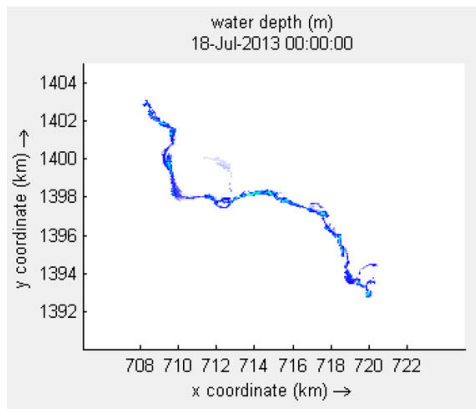

(c)

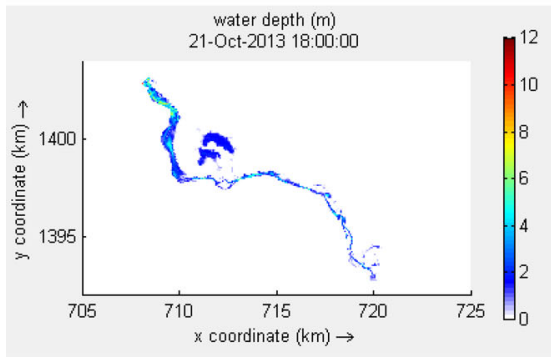

(b)

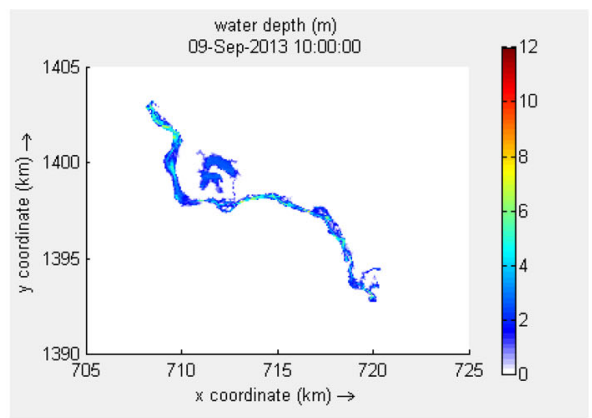

(d)

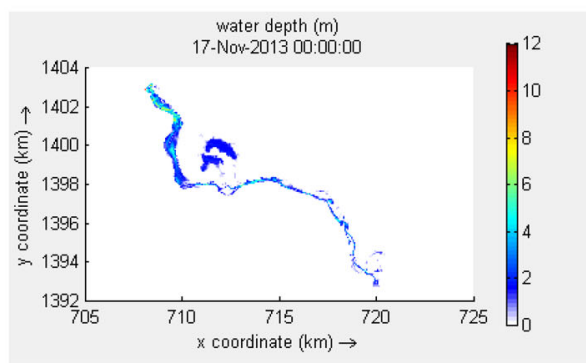

Fig. 11 Inundation mechanism of the Musa Maya through the constructed connection canal considering average hydrologic year a) and b) filling phase, c) drainage phase and d) isolation phase 
(a)

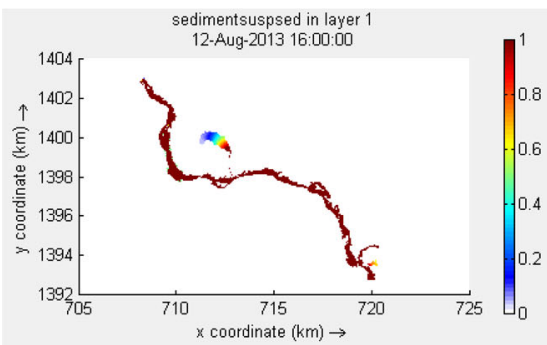

(c)

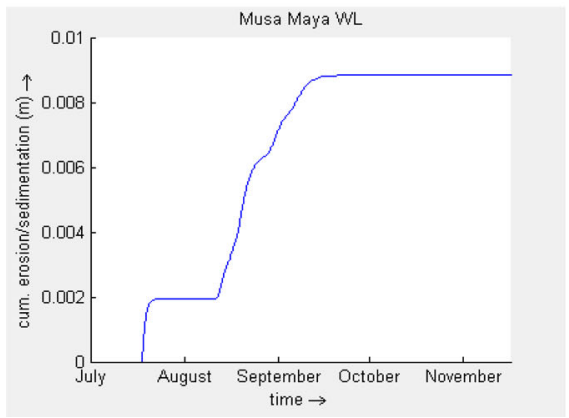

(b)

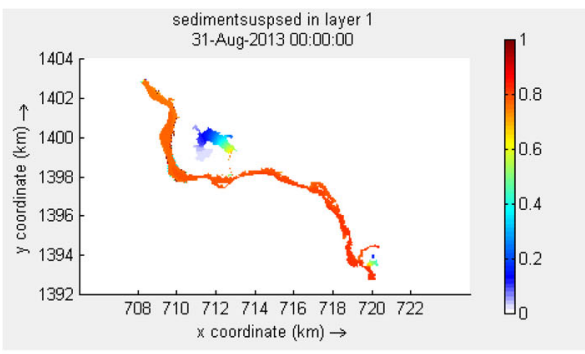

(d)

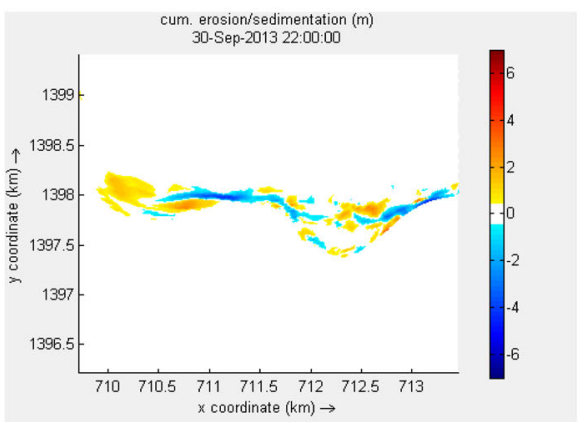

Fig. 12 sediment concentartion $\left(\mathrm{kg} / \mathrm{m}^{3}\right),(\mathbf{a})$ at the beginning of the flood season (b) at the end of the flood season and (c) and (d) sedimentation in the Maya and along the connection canal.

of water from the river to the Maya "filling phase" (Fig. 13a). The large magnitude of the river peak flood results in a complete inundation of the Maya and flooding of the river floodplain (Fig. 13b). The large magnitude of the river peak flood results in a complete inundation of the Maya and flooding of the river floodplain. The Maya is inundated with variable water depths according to the Maya's topography with a maximum depth of $4 \mathrm{~m}$. As the river water level falls, the drainage phase begins, and it continues until the water level is low enough that stagnant and dynamic waters are completely isolated (Fig. 13c-d). The Maya is left with an average water depth of about $2 \mathrm{~m}$ and estimated water volume of $2.40 \times 10^{6} \mathrm{~m}^{3}$. In addition to Maya's inundation, the floodplain is also left with many small water pools. This water is normally consumed by wild animals, evaporates or infiltrates to recharge groundwater.

The model has shown that sediment is transported into and out of the Musa Maya at a rate of $3 \mathrm{~kg} / \mathrm{m}^{3}$ during July and decreased gradually to less than $0.3 \mathrm{~kg} / \mathrm{m}^{3}$ in October. This situation can be maintained for years or decades, depending on the morphological changes of the main river channel and the connection canal as a result of changes at the upstream part of the catchment. These changes were found to be strongly accelerated during extreme floods. Within the river cross section just downstream of the connection canal, very high bank erosion on the right and deposition at the middle of the cross section are observed (Fig. 14a). The result was the formation of an island. On the left bank, the river bed was silted up. Morphological dynamics within the connection canal itself is another important factor in the evolution of the Maya and its aquatic components. Results show the siltation process at the connection canal outlets. The deposition at the inlet of the connection canal and the formation of the small delta at the tail of the connection canal at its connection with the Maya is another evidence of the siltation process (Fig. 14b). 
(a)

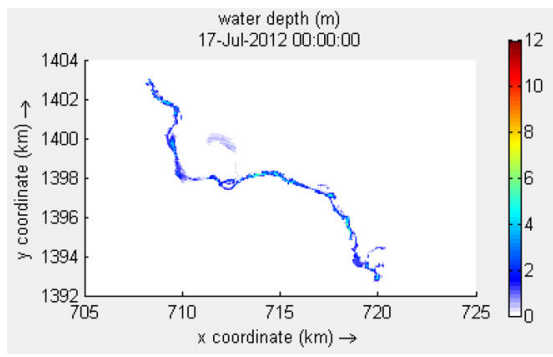

(c)

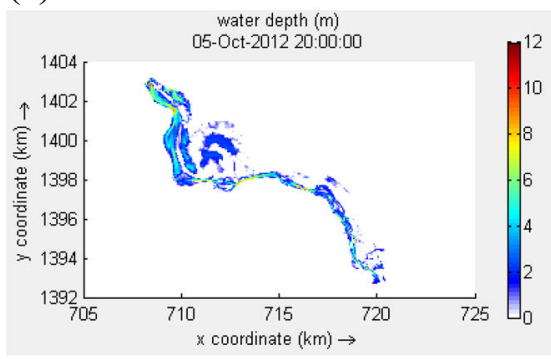

(b)

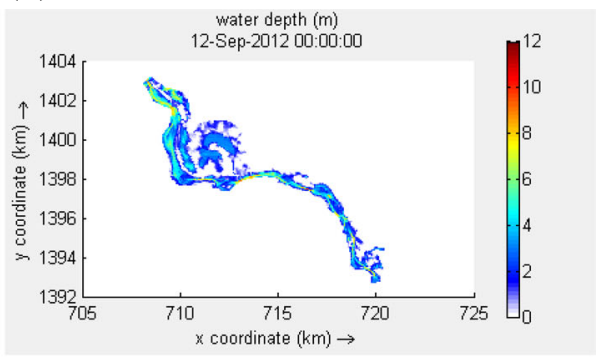

(d)

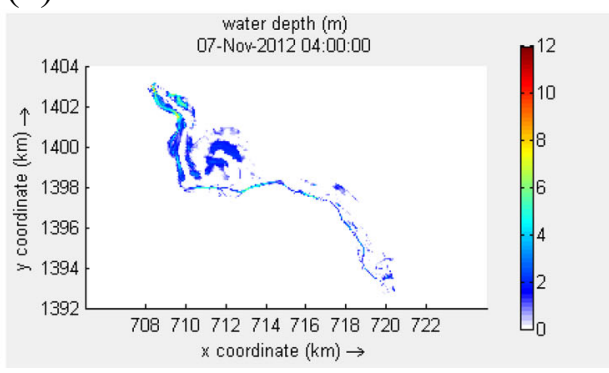

Fig. 13 Inundation mechanism of the Musa Maya through the constructed connection canal considering wet hydrologic year (a) and (b) filling phase, (c) drainage phase and (d) isolation phase

\subsubsection{Scenario 3: Dry Hydrologic Year under the Existing System with the Constructed Connection Canal}

In this scenario, the system was simulated using the flow of the year 2015 as a representative for the dry hydrologic years $\left(0.95 \times 10^{9} \mathrm{~m}^{3} /\right.$ year $)$ in the existing system. Same as scenario 1 and scenario 2, the results show that the constructed connection canal conveys the water flow from the river to the Maya. But with such small flow magnitude, the Maya is inundated to shallow water depth with a maximum depth of about $2.3 \mathrm{~m}$ (Fig. 15a-b) before the drainage and isolation phases begin. The Maya is left with an average water depth of $1.12 \mathrm{~m}$ and estimated water volume of $1.344 \times 10^{6} \mathrm{~m}^{3}$ (Fig. 15c-d).

(a)

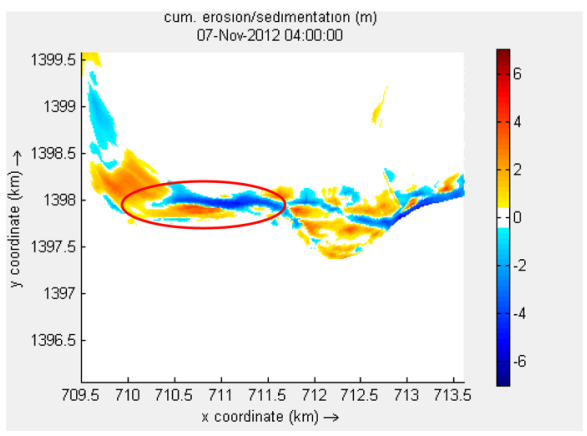

(b)

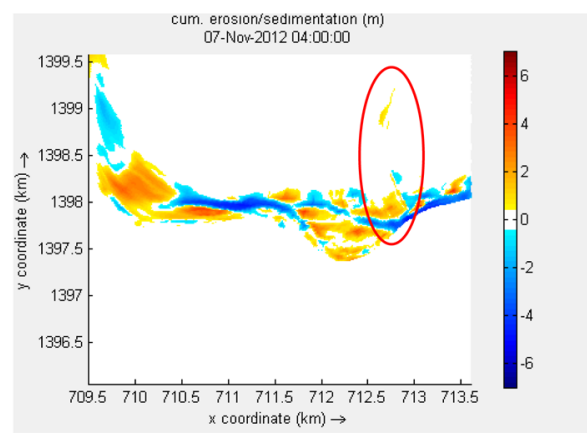

Fig. 14 Total cumulative erosion and sedimentation (a) at the cross section just downstream of the connection canal, and (b) along the connection canal 
Within the river cross section just downstream of the connection canal, bank erosion on the right bank and deposition at mid cross section were observed. Considering the small volume of water that remains in the Maya, Fig. 16a has shown that the sediment deposition in the Maya is very low $\left(4 \mathrm{~mm} \mathrm{yr}^{-1}\right)$. No morphological changes were observed in the connection canal (Fig. 16b).

\subsubsection{Scenario 4: Average Hydrologic Year under the Natural System without the Connection Canal}

In this scenario, the system was simulated using the flow of the year 2013 as a representative for the average hydrologic years under the natural system (without the connection canal). The results show that during average years, water is only flowing within the river channel (Fig. 17). Floodplain including the pilot Maya remains dry with no connection with the river water. This result was supported by our observation during the years 2009, 2010 and 2011 and our investigation with wildlife personnel on the inundation history of the Maya.

\subsubsection{Scenario 5: Wet Hydrologic Year under the Natural System without the Connection Canal}

In this scenario, the system was simulated using the flow of the year 2012 as a representative for the wet hydrologic years under the natural system. The results show that when the river water overflows the bank-full level, the floodplain is inundated through the lowest area and the flood wave rises to a water level enough to inundate the Maya "filling phase". The Maya is completely inundated if the level in the river at the cross section just upstream of the Maya

(a)

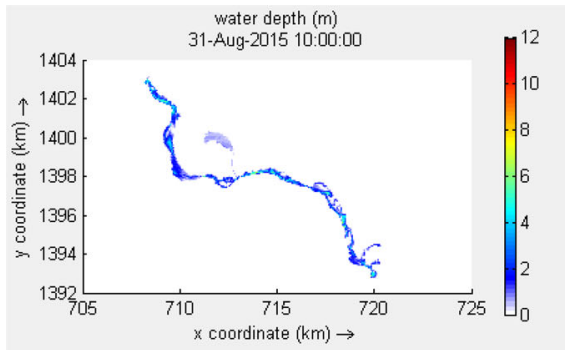

(c)

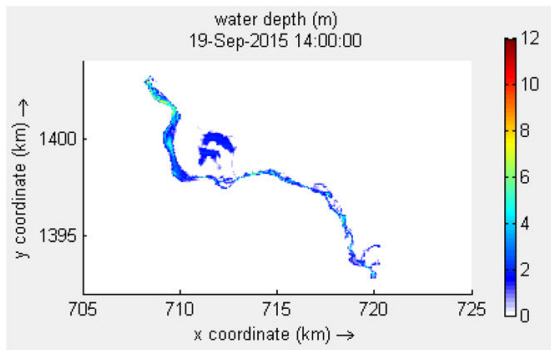

(b)

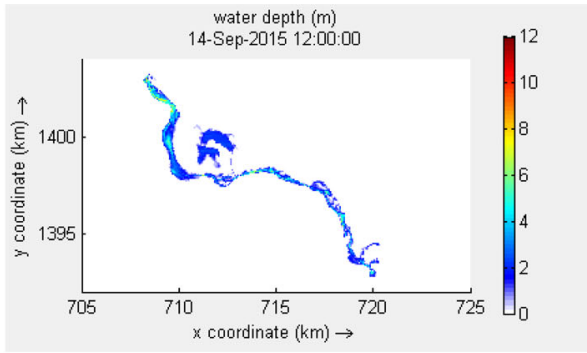

(d)

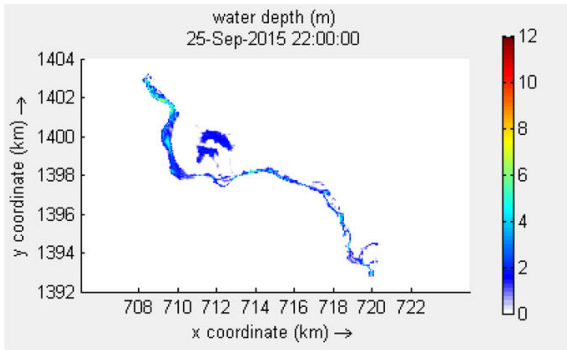

Fig. 15 Inundation mechanism of the Musa Maya through the constructed connection canal considering dry hydrologic year (a) and (b) filling phase, (c) drainage phase and (d) isolation phase 
(a)

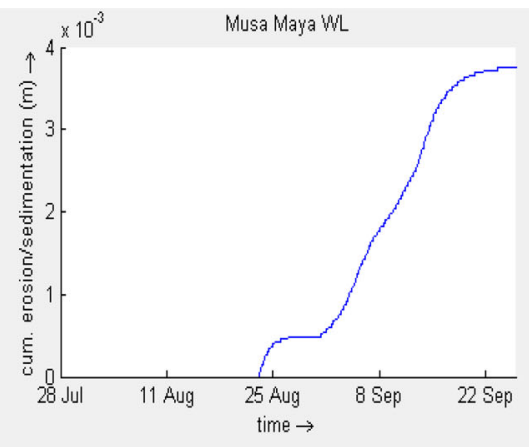

(b)

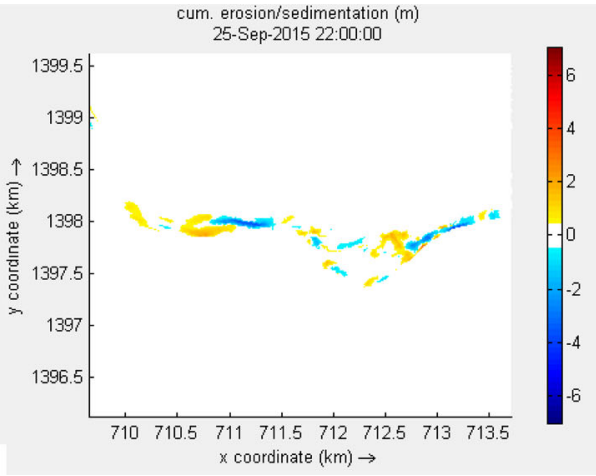

Fig. $16 \mathbf{a}$ the sediment deposition in the Maya, and $\mathbf{b}$ the morphological changes in the connection canal.

rises to $471.75 \mathrm{~m}$ (Fig. 18a-b). As the water level falls, the drainage phase begins which continues until reaching the isolation. The drainage and isolation are occurring at the end of September and the floodplain remains with isolated Maya and many small water pools (Fig. 18c-d). The Maya is left with relatively high water-depth of about $2.7 \mathrm{~m}$ and estimated water volume of $3.240 \times 10^{6} \mathrm{~m}^{3}$. At this stage water in the Maya becomes stagnant and the suspended sediment carried by the remaining water starts to deposit.

Sediment is transported into the Musa Maya through overland flow during mid-September to late September (period of low sediment concentration) at a flow rate between 0.2 to $0.7 \mathrm{~kg} /$ $\mathrm{m}^{3}$ (Fig. 19a). By the end of the isolation phase, the stagnant water in the Maya is left with sediment concentration of less than $0.4 \mathrm{~kg} / \mathrm{m}^{3}$ (Fig. 19b). Considering the low sediment

(a)

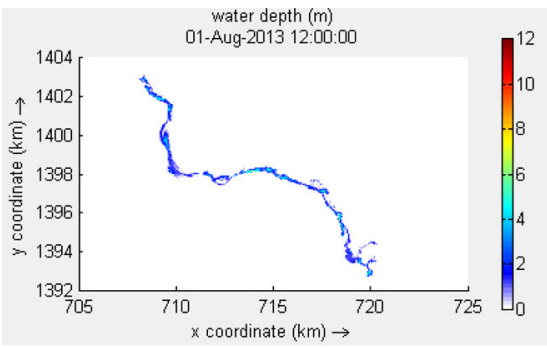

(c)

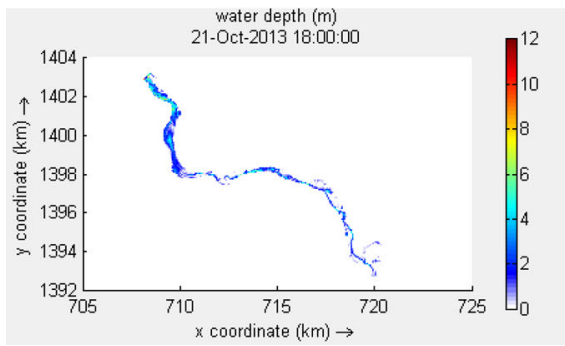

(b)

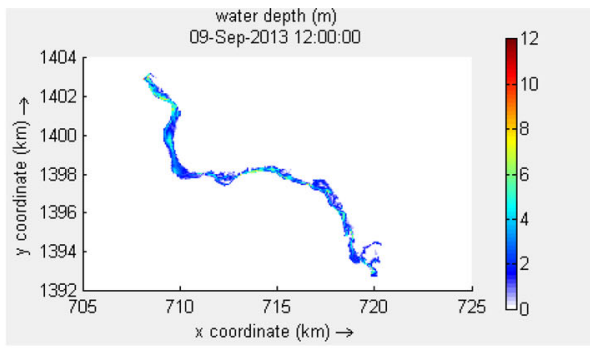

(d)

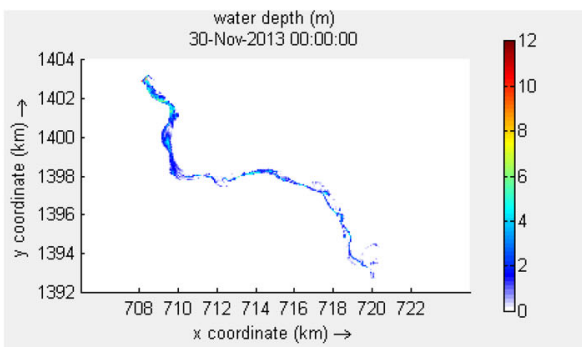

Fig. 17 During average hydrologic year, water is only flowing within the river channel. Floodplain including the pilot Maya remains dry 
(a)

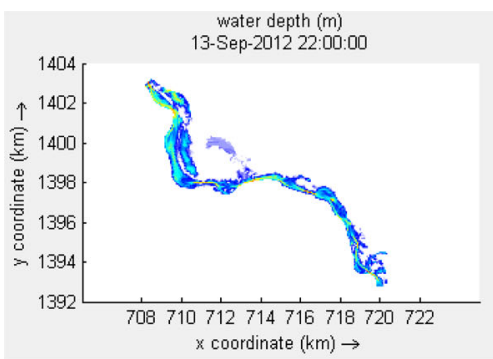

(c)
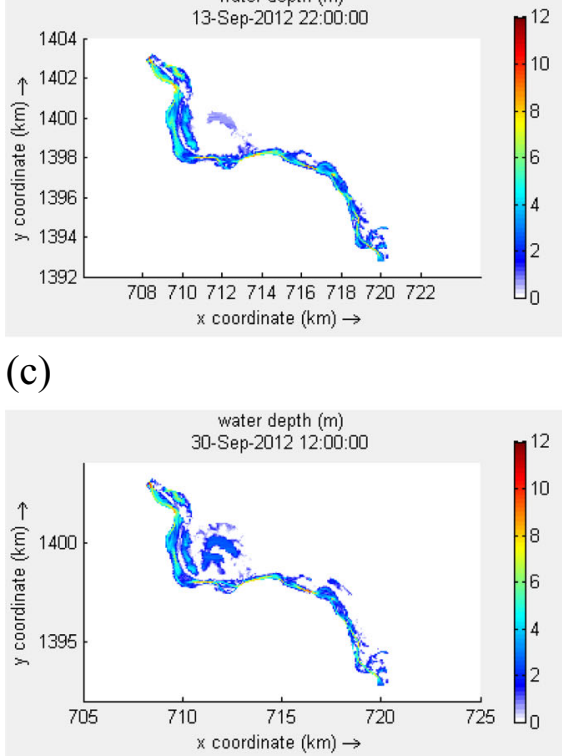

(b)

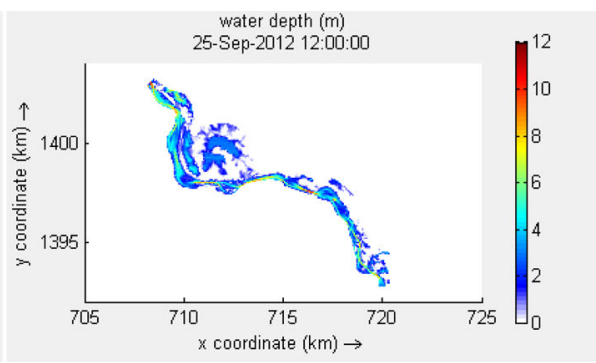

(d)

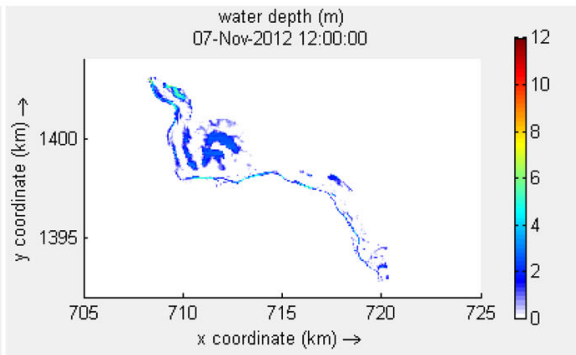

Fig. 18 Inundation mechanism of the Musa Maya under natural system through overland flow (a) and (b) filling phase, (c) drainage phase and (d) isolation phase

concentration in water entering the Maya, Fig. 19c shows that the sediment deposition in the Maya is very low (less than $8 \mathrm{~mm} \mathrm{yr}^{-1}$ ).

\subsubsection{Scenario 6: Dry Hydrologic Year under the Natural System without the Connection Canal}

In this scenario, the system was simulated using the flow of the year 2015 as a representative for the dry hydrologic years under the natural system. Similar to scenario 5, the model results show that during dry years the water only flows within the river channel. Floodplain including the pilot Maya remains dry with no connection with the river water (Fig. 20). Summary of the six scenarios is presented in Table 2.

\section{Conclusions}

This article presents the inundation mechanism and the morphological dynamics of the Mayas wetlands using a quasi-3D model. The study aims to improve our understanding of the filling mechanism of the Mayas wetlands and the effect of morphological change on filling of the Mayas. Shuttle Radar Topography Mission data was used to generate the topography. However, since the vertical accuracy of the $90 \mathrm{~m}$ resolution DEM performs poorly in areas of moderate topographic variation and forestry area, a field topographic survey was conducted using an ordinary level and GPS to generate a DEM with higher accuracy with vertical error of $0.008 \mathrm{~m}$ and horizontal error of $\pm 3 \mathrm{~m}$ within the model domain. Channel topography was approximated using the measured cross sections of the Dinder river reach upstream and 
(a)

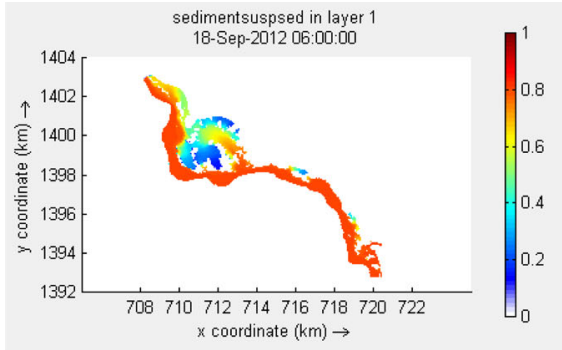

(c)

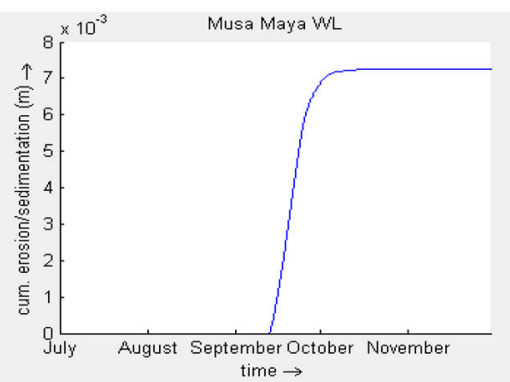

(b)

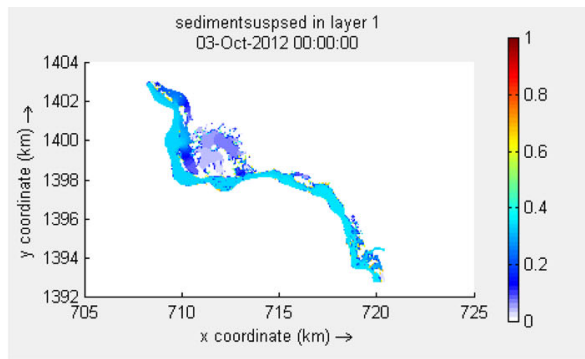

(d)

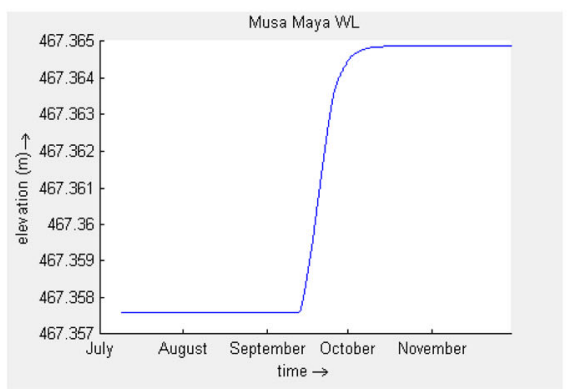

Fig. 19 sediment concentration $\left(\mathrm{kg} / \mathrm{m}^{3}\right)$, transported into the Maya, (a) at the filling phase, (b) at the isolation phase, and (c) the deposition rate in the Maya.

(a)

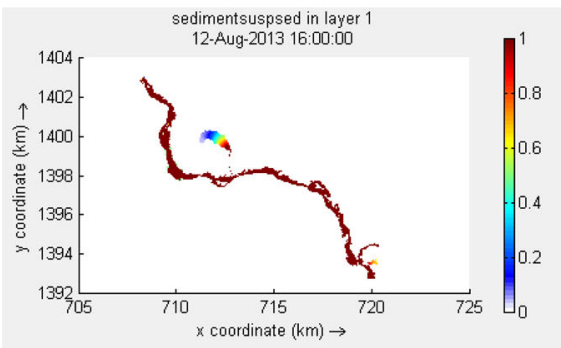

(c)

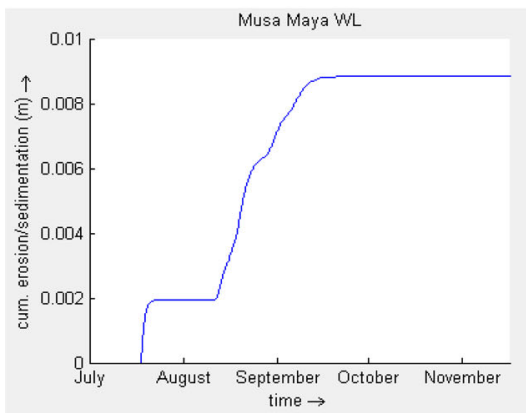

(b)

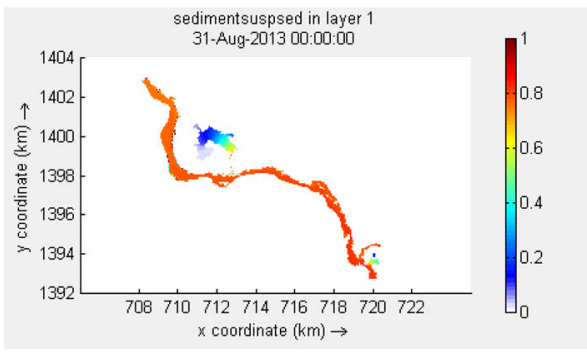

(d)

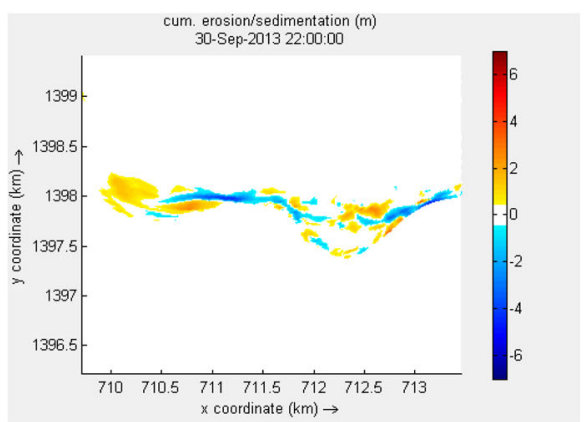

Fig. 20 During the dry hydrologic year, water only flows within the river channel. Floodplain including the pilot Maya remains dry 


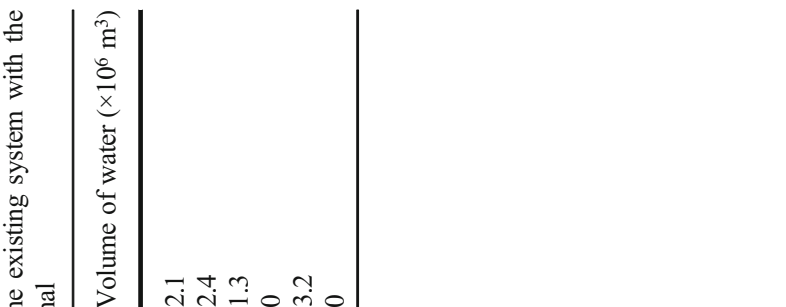

तin MO mo

鄫.

है ڤ్

롱

空

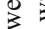

密

टे

을

.용

䢔

战

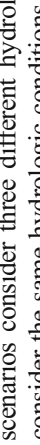

ఏ

웜

율

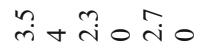

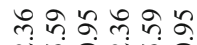

तino तino

密

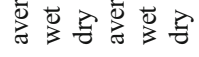

苋.气

遂品

$\stackrel{乛}{\Xi}$

过 홓

胥

产

Ð

4

苟

寻

늘

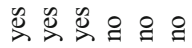


downstream of the pilot Maya. The approximation of the topography creates uncertainty to the bed topography. This is reflected by the morphological predictions.

In conclusion, this study highlighted the value of integrating results from field observation and modelling in understanding the flooding and sediment transport processes in the Mayas wetlands. The development of a quasi-3D numerical model improved our understanding of the hydrological functioning of the Mayas wetlands, allowing the quantification of the effects of possible future hydrological changes on Mayas inundation. However, considering the uncertainty in the model input data beside unavailability of required data for model validation, the hydrodynamic and morphological quantification in this study could be less or more than the actual values. Despite that, the model helped to understand the expected morphological impact and trends of the Maya development.

The methodology applied in this study can be applied to other Mayas wetlands, in particular, the wetlands that are located along Dinder River. The findings of this study present how Mayas wetlands are inundated and drain, and how the constructed connection canal has changed the hydrology of the Musa Maya and the morphology of the Dinder River.

Conservation of the Mayas wetlands ecosystems is crucial for sustainable development and utilization of the rich natural resources in the Dinder National Park. This issue requires the integration of models that include both hydrodynamic and morphological models such as those presented in this study. As is often the case, the use of integrated modelling, besides the lack of reliable data introduces model uncertainties. Unfortunately, such unavoidable uncertainties are difficult to quantify in integrated modelling in general and were not quantified in this study.

Furthermore, effective management of the Dinder basin-wide requires international cooperation as the basin is shared between Ethiopia and Sudan. Though the present study looks at the wetland flooding mechanism and sediment transport processes, it is important that this analysis is further expanded to include indicators associated with the ecological status of the Mayas wetlands ecosystem, which will be part of our next investigation.

Acknowledgements This study was carried out as part of a $\mathrm{PhD}$ research program of the first author entitled 'Land degradation in the Dinder and Rahad basins: Interactions between hydrology, morphology and ecohydrology in the Dinder National Park, Sudan", which is funded by the Netherland Fellowship Program (NFP). We also thank the Hydraulics Research Center of the Ministry of Irrigation and Water Resources -Sudan for providing the hydrological data.

\section{Compliance with Ethical Standards}

\section{Conflict of Interest None.}

Open Access This article is licensed under a Creative Commons Attribution 4.0 International License, which permits use, sharing, adaptation, distribution and reproduction in any medium or format, as long as you give appropriate credit to the original author(s) and the source, provide a link to the Creative Commons licence, and indicate if changes were made. The images or other third party material in this article are included in the article's Creative Commons licence, unless indicated otherwise in a credit line to the material. If material is not included in the article's Creative Commons licence and your intended use is not permitted by statutory regulation or exceeds the permitted use, you will need to obtain permission directly from the copyright holder. To view a copy of this licence, visit http://creativecommons.org/licenses/by/4.0/. 


\section{References}

AbdelHameed SM, Awad NM, ElMoghraby AI, Hamid AA, Hamid SH, Osman OA (1997) Watershed management in the Dinder National Park, Sudan. Agric For Meteorol 84:89-96

Arthington ÁH, Naiman RJ, Mcclain ME, Nilsson C (2010) Preserving the biodiversity and ecological services of rivers: new challenges and research opportunities. Freshw Biol 55:1-16

Basheer AK, Lu H, Omer A, Abubaker B, Abdelgader AMS (2016) Impacts of climate change under CMIP5 RCP scenarios on the streamflow in the Dinder River and ecosystem habitats in Dinder National Park, Sudan. Hydrol Earth Syst Sci 20:1331-1353

Bewket W, Sterk G (2005) Dynamics in land cover and its effect on stream flow in the Chemoga watershed, Blue Nile basin, Ethiopia. Hydrol Process 19:445-458

Bewket W, Teferi E (2009) Assessment of soil erosion hazard and prioritization for treatment at the watershed level: case study in the Chemoga watershed, Blue Nile basin, Ethiopia. Land Degrad Dev 20:609-622

Block P, Rajagopalan B (2006) Interannual variability and ensemble forecast of upper Blue Nile Basin Kiremt season precipitation. J Hydrometeorol 8:327-343

Bracken LJ, Croke J (2007) The concept of hydrological connectivity and its contribution to understanding runoff-dominated geomorphic systems. Hydrol Process 21:1749-1763

Bracken LJ, Turnbull L, Wainwright J, Bogaart P (2015) Sediment connectivity: a framework for understanding sediment transfer at multiple scales. Earth Surf Process Landf 40:177-188

Bradley C (1997) The hydrological basis for conservation of floodplain wetlands: implications of work at Narborough bog, UK. Aquat Conserv Mar Freshwat Ecosyst 7:41-62

Brierley G, Fryirs K, Jain V (2006) Landscape connectivity: the geographic basis of geomorphic applications. Area 38:165-174

Cook BJ, Hauer FR (2007) Effects of hydrologic connectivity on water chemistry, soils, and vegetation structure and function in an intermontane depressional wetland landscape. Wetlands 27:719-738

Dasmann W (1972). Development and management of the Dinder N. park and its wildlife: a report to the government of Sudan. FAO no TA 3113 , Rome

De Steven D, Toner MM (2004) Vegetation of upper coastal plain depression wetlands: environmental templates and wetland dynamics within a landscape framework. Wetlands 24:23-42

Deltares (2010). Delft 3D-flow user manual, Simulation of Multidimensional Hydrodynamic Flows and Transport Phenomena, Delft, the Netherlands, 38-43

FAO (1986). Ethiopian highland reclamation study. ethiopia. final report. FAO. Rome :37-46

Fernandes JN, Leal JB, Cardoso AH (2018). Influence of floodplain and riparian vegetation in the conveyance and structure of turbulent flow in compound channels. In: E3S web of conferences, 2018. EDP Sciences, p 06035

Glińska-Lewczuk K (2009) Water quality dynamics of oxbow lakes in young glacial landscape of NE Poland in relation to their hydrological connectivity. Ecol Eng 35:25-37

Gomoiu M (1998). Notes on the fauna and flora of the danube delta NEAR summer school

Gumiri S, Iwakuma T (2002) The dynamics of rotiferan communities in relation to environmental factors: comparison between two tropical oxbow lakes with different hydrological conditions. Internationale Vereinigung für Theoretische und Angewandte Limnologie: Verhandlungen 28:1885-1889

Hassaballah K, Mohamed YA, Uhlenbrook S (2016) The Mayas wetlands of the Dinder and Rahad: tributaries of the Blue Nile Basin (Sudan). In: Finlayson CM, Milton GR, Prentice RC, Davidson NC (eds) The wetland book: II: distribution. Description and Conservation. Springer Netherlands, Dordrecht, pp 1-13. https://oi. org/10.1007/978-94-007-6173-5 223-1

Hassaballah K, Mohamed Y, Uhlenbrook S, Biro K (2017) Analysis of streamflow response to land use and land cover changes using satellite data and hydrological modelling: case study of Dinder and Rahad tributaries of the Blue Nile (Ethiopia-Sudan). Hydrol Earth Syst Sci 21:5217-5242. https://doi.org/10.5194/hess-215217-2017

Heckmann T, Cavalli M, Cerdan O, Foerster S, Javaux M, Lode E, Smetanová A, Vericat D, Brardinoni F (2018) Indices of sediment connectivity: opportunities, challenges and limitations. Earth Sci Rev 187:77-108

Hurni H, Tato K, Zeleke G (2005) The implications of changes in population, land use, and land management for surface runoff in the upper Nile basin area of Ethiopia. Mt Res Dev 25:147-154

Lesser G, Roelvink J, Van Kester J, Stelling G (2004) Development and validation of a three-dimensional morphological model. Coast Eng 51:883-915

Lew S, Glińska-Lewczuk K, Burandt P, Obolewski K, Goździejewska A, Lew M, Dunalska J (2016) Impact of environmental factors on bacterial communities in floodplain lakes differed by hydrological connectivity. Limnologica 58:20-29

Li Y, Zhang Q, Cai Y, Tan Z, Wu H, Liu X, Yao J (2019) Hydrodynamic investigation of surface hydrological connectivity and its effects on the water quality of seasonal lakes: insights from a complex floodplain setting (Poyang Lake, China). Sci Total Environ 660:245-259 
Mukul M, Srivastava V, Mukul M (2015) Analysis of the accuracy of shuttle radar topography Mission (SRTM) height models using international global navigation satellite system service (IGS) network. J Earth Syst Sci 124:1343-1357

Mutasim B, Frazer T (2004). Paper (10) protected areas management. Doi:https://studylib.net/doc/7332179 /paper\%2D\%2D10\%2D\%2Dprotected-areas-management. Accessed 25 June 2019

Nash JE, Sutcliffe JV (1970) River flow forecasting through conceptual models part I-A discussion of principles. J Hydrol 10:282-290

Nowell A, Jumars P (1984). Flow environments of aquatic benthos Annual review of ecology and systematics: 303-328

Omer A, Ali Y, Roelvink J, Dastgheib A, Paron P, Crosato A (2015) Modelling of sedimentation processes inside Roseires reservoir (Sudan). Earth Surface Dynamics 3:223-238

Partheniades E (1965) Erosion and deposition of cohesive soils. J Hydraul Div 91:105-139

Popescu I, Cioaca E, Pan Q, Jonoski A, Hanganu J (2015) Use of hydrodynamic models for the management of the Danube Delta wetlands: the case study of Sontea-Fortuna ecosystem. Environ Sci Pol 46:48-56

Rebelo L-M, Johnston R, Hein T, Weigelhofer G, D’Haeyer T, Kone B, Cools J (2012) Challenges to the integration of wetlands into IWRM: the case of the inner Niger Delta (Mali) and the Lobau floodplain (Austria). Environ Sci Pol 34:58-68

Santisteban JI, Mediavilla R, de Frutos LG, Cilla IL (2019) Holocene floods in a complex fluvial wetland in Central Spain: environmental variability, climate and time. Glob Planet Chang 181:102986

Tan Z, Li Y, Xu X, Yao J, Zhang Q (2019) Mapping inundation dynamics in a heterogeneous floodplain: insights from integrating observations and modeling approach. J Hydrol 572:148-159

Teferi E, Uhlenbrook S, Bewket W, Wenninger J, Simane B (2010) The use of remote sensing to quantify wetland loss in the Choke Mountain range, upper Blue Nile basin, Ethiopia. Hydrol Earth Syst Sci 14:2415-2428

Teferi E, Bewket W, Uhlenbrook S, Wenninger J (2013) Understanding recent land use and land cover dynamics in the source region of the upper Blue Nile, Ethiopia: spatially explicit statistical modeling of systematic transitions. Agric Ecosyst Environ 165:98-117. https://doi.org/10.1016/j.agee.2012.11.007

Tooth S, McCarthy T, Rodnight H, Keen-Zebert A, Rowberry M, Brandt D (2014) Late Holocene development of a major fluvial discontinuity in floodplain wetlands of the Blood River, eastern South Africa. Geomorphology 205:128-141. https://doi.org/10.1016/j.geomorph.2011.12.045

Van Rijn LC (1984) Sediment transport, part II: suspended load transport. J Hydraul Eng 110:1613-1641

Wilson M, Bates P, Alsdorf D, Forsberg B, Horritt M, Melack J, Frappart F, Famiglietti J (2007) Modeling largescale inundation of Amazonian seasonally flooded wetlands. Geophys Res Lett 34(15)

Yu X, Hawley-Howard J, Pitt AL, Wang J-J, Baldwin RF, Chow AT (2015) Water quality of small seasonal wetlands in the Piedmont ecoregion, South Carolina, USA: effects of land use and hydrological connectivity. Water Res 73:98-108

Zeleke G, Hurni H (2001) Implications of land use and land cover dynamics for mountain resource degradation in the northwestern Ethiopian highlands. Mt Res Dev 21:184-191

Zeug S, Winemiller K (2008) Relationships between hydrology, spatial heterogeneity, and fish recruitment dynamics in a temperate floodplain river. River Res Appl 24:90-102

Publisher's Note Springer Nature remains neutral with regard to jurisdictional claims in published maps and institutional affiliations.

\section{Affiliations}

\section{Khalid Hassaballah $^{1,2,3} \cdot$ Yasir Mohamed ${ }^{1,2,3} \cdot$ Amgad Omer $^{4} \cdot$ Stefan Uhlenbrook ${ }^{1,2,5}$}

1 IHE-Delft Institute for Water Education, P.O. Box 3015, 2601DA, Delft, The Netherlands

2 Delft University of Technology, P.O. Box 5048, 2600 GADelft, The Netherlands

3 The Hydraulics Research Center, P.O. Box 318, Wad Medani, Sudan

4 Deltares, P.O. Box 177, 2600 MHDelft, The Netherlands

5 International Water Management Institute (IWMI) - Colombo 127, Sunil Mawatha, Battaramulla, Colombo, Sri Lanka 